\title{
Adapted Bailenger method improves the rate of Ascaris suum eggs recovery from liquid pig manure compost
}

\section{Mariangela Facco de Sá ${ }^{1}$ Ricardo Aymay Gonçalves ${ }^{1}$ Cristiana Marder $^{1}$ Matheus Dellamea Baldissera ${ }^{1}$ Camila Belmonte de Oliveira ${ }^{1}$ Jessica Caroline Gomes Noll ${ }^{1}$ Filipe Silva ${ }^{1}$ Silvia Gonzalez Monteiro ${ }^{{ }^{*}}$}

\author{
'Departamento de Microbiologia e Parasitologia, Universidade Federal de Santa Maria (UFSM), 97105-900, Santa Maria, RS, Brasil. E-mail: \\ sgmonteiro@uol.com.br. "Corresponding author.
}

ABSTRACT: Liquid pig manure (LPM) is widely used as a compost fertilizer for vegetable crops destined for human consumption. However, these wastes may contain parasites eggs, such as the nematode Ascaris suum, that pose serious health risks to humans. We attempted to determine the most appropriate technique for recovering A. suum eggs from LPM compost. Samples were collected from two waste sources during composting, including 23 samples containing LPM, sawdust, and wood shavings, and 14 samples of LPM alone-both in triplicate. Samples were analyzed using several different recovery methods. Recovery of eggs by the modified Bailenger method with adaptations was significantly more effective and recovered 57\% more eggs than by the modified Bailenger method alone. Willis-Mollay method, modified Faust method, and the simple sedimentation technique only recovered $4.4 \%, 13.9 \%$, and $26 \%$ of eggs, respectively, compared with the modified Bailenger method with adaptations, indicating that the adjustments made to the Bailenger method were key to improving the recovery of $\boldsymbol{A}$. suum eggs from compost and LPM.

Key words: helminth eggs, organic decomposition, residues, parasites

\section{Adaptações no método de Bailenger melhora taxa de recuperação de ovos de Ascaris suum em dejetos líquidos de suínos compostado}

RESUMO: Dejetos líquidos de suínos (DLS) são amplamente utilizado como adubo para as culturas vegetais destinados ao consumo humano. No entanto, estes residuos podem conter os ovos de parasitas, tais como o nematoide Ascaris suum, que apresentam riscos graves para a saúde dos seres humanos. Neste estudo tentamos determinar a técnica mais apropriada para a recuperação de ovos de A. suum no composto de DLS e nos dejetos líquidos. Foram coletadas amostras de dois tratamentos destes resíduos, que consiste de 23 amostras de DLS + serragem + maravalha e 14 amostras de DLS sozinhos, todos em triplicata. Em ambos, dejetos líquidos e dejetos compostado foram analisados usando um método modificado Bailenger (BM), um método de Faust modificado (FM), o método de Willis-Mollay (WM), sedimentação simples (SS), e pelo método de Bailenger modificado com adaptações (BMA). A recuperação de ovos pelo Método BMA foi significativamente mais eficaz do que pela BM, com 57\% mais ovos recuperados usando a técnica de BMA; além disso, o WM, FM, e o método SS recuperaram 4,4\%, 13,9\% e 26\%, respectivamente, em comparação com o método BMA, indicando que os ajustes feitos com o método BM foram fundamentais para melhorar a recuperação de ovos de A. suum ovos em dejetos compostados e DLS puro.

Palavras-chave: ovos de helmintos, decomposição organica, resíduos, parasitas.

\section{INTRODUCTION}

Various technologies have been explored to reduce the environmental impacts of pig manure due to greenhouse gas emissions and microbial contamination. However, few studies have applied such technologies to reduce contamination of manure by parasites (DOS SANTOS et al., 2015). The great demand for food to meet global population growth necessitates improvements to food security while simultaneously minimizing environmental damage (HECK et al., 2013).

Thus, there is a growing need to manage the waste generated by the pork processing industry appropriately and effectively to reduce environmental damage. Automated composting, an aerobic process in which liquid pig manure (LPM) is distributed and mixed with a solid matrix (typically wood shavings and sawdust) that provides aeration and steam precipitation of the compost, is one potential alternative for treating LPM (SERPA et al., 2013). For optimal results, the process requires thermophilic temperatures to be attained via the mixing of substrates with material that has a high carbon:nitrogen $(\mathrm{C}: \mathrm{N})$ ratio, thereby increasing aerobic microbial activity (SÁ et al., 2014). Such high temperatures are essential to sanitize composted manure, as they incapacitate any parasites that may be present.

Studies focusing on parasite elimination from LPM remain scarce, limiting the applicability 
of LPM as a crop fertilizer (PALHARES, 2012). Techniques for parasite recovery from the final compost are still inadequately defined. Therefore, it is necessary to adapt established techniques for the treatment of sewage sludge or LPM through anaerobic reactors (PINTO et al., 2014). Compost based on LPM is rich in urine, water, fur, feed, and other material that provide fertile grounds for pathogen egg, larva, cyst, and oocyst fixation (DOS SANTOS et al., 2011).

The parasitic nematode Ascaris suum, which has a life cycle very similar to that of the parasite Ascaris lumbricoides, is often present in LPM and poses a risk to human health (LELES et al., 2012). Several successful experimental infections have demonstrated that $\boldsymbol{A}$. lumbricoides can establish in pigs and $\boldsymbol{A}$. suum can establish in humans, with both exhibiting full life cycles in the respective hosts (JUNGERSEN et al., 1996). Existing techniques for egg recovery may underestimate egg loads, given that the final compost usually has low moisture and high organic matter content.

The goal of the present study was to explore the relative effectiveness of methods that are currently used to recover $\boldsymbol{A}$. suum eggs from LPM compost.

\section{MATERIALS AND METHODS}

Automated composting platforms were the experimental unit in the present study. We used substrates consisting of a mixture of wood shavings $(30 \%)$ and sawdust $(70 \%)$ with a high carbon:nitrogen $(\mathrm{C}: \mathrm{N})$ ratio, an essential component of efficient composting. Swine manure was obtained from pigs in the finishing phase that were raised in conventional production systems and kept under full confinement until slaughter.

Manure was stored in interconnected polyethylene boxes and pumped onto the composting platforms. A total of $1 \mathrm{~L}$ of sample material was collected and examined for the presence of parasites, using several different techniques in order to compare them. Compost samples $(100 \mathrm{~g})$ were collected at four heights $(20 \mathrm{~cm}, 40 \mathrm{~cm}, 60 \mathrm{~cm}$, and $80 \mathrm{~cm})$, with three replicates (a total of nine samples), 1 day before fresh manure was added to the windrow. The samples were placed in sterile vials and stored on ice in a Styrofoam box, then transported to the Parasitology Laboratory of the Universidade Federal de Santa Maria for parasite identification. A total of 23 samples of compost (composed of LPM, sawdust, and wood shavings) and 14 samples of LPM alone were collected. A. suum eggs reported in the compost samples were identified by size and specific morphological characteristics, such as shape, thickness of the outer membrane, inner content, and other structures, in accordance with established criteria for identification of helminth eggs (PINTO et al., 2014).

We compared the efficiency of four different methods of $\boldsymbol{A}$. suum egg recovery: (i) a modified Faust method (FM) (COELHO et al., 2002), which is based on the principle of centrifugal flotation at a density $(1: 30)$ larger than that used in the modified method (1:18), facilitating the gathering of helminth eggs of different densities; (ii) the Willis-Mollay method (WM), which is based on the principle of spontaneous flotation in a solution of saturated sodium chloride $(\mathrm{NaCl})$ at a density of $1: 18$; (iii) simple sedimentation (SS), which consists of mixing the material to be analyzed with water and then simply allowing gravity to separate denser material from less-dense material (OLIVEIRA \& GERMANO, 1992); and (iv) a modified Bailenger method (BM) (AYRES \& MARA, 1996), which involves washing of sediments containing helminth eggs in an aceto-acetic buffer at $\mathrm{pH} 4.5$ and ether to separate the material into distinct phases, after which the pellets are suspended in a $30 \%$ zinc sulfate solution and the resultant supernatant is analyzed using a McMaster chamber. In addition to these techniques, we also performed a modified Bailenger method with adaptations (MBA; described below).

The first adaptation of the modified Bailenger technique occurred early in the process, immediately after the four aliquots of the compost were homogenized, wherein a 100 -g sample was added to $200 \mathrm{~mL}$ of sterile deionized water. The material was agitated for $30 \mathrm{~min}$ in a horizontal roller agitator to promote additional egg recovery, and the process was repeated in triplicate. Aliquots were strained into a sedimentation cup with a sieve containing gauze that was folded four times, until the cup contained $1,000 \mathrm{~mL}$ of distilled water. After $24 \mathrm{~h}$ of sedimentation, the supernatant was discarded and the decanted material was washed three times with distilled water at 2-h intervals.

The sediment was then placed into 15 $\mathrm{mL}$ Falcon tubes; the used cups were washed with a solution of distilled water and $1 \%$ Tween 80 to recover the eggs remaining in the cups. The samples were then centrifuged for $15 \mathrm{~min}$ at $2500 \mathrm{rpm}$ to separate the solid fraction, and the supernatant was discarded. Recovered pellets were partitioned into four equal aliquots (volume in weight), to which sterile distilled water was added to reach a total 
volume of $15 \mathrm{~mL}$. The contents were homogenized by vortexing and then centrifuged again to remove any Tween 80 residue. For the MBA method, acetoacetic buffer solution ( $\mathrm{pH} 4.9)$ was added to the Falcon tubes at a 1:1 ratio, using diethyl ether to fill the tube to reach a volume equivalent to twice the amount of sediment.

Tubes were vortexed for $1 \mathrm{~min}$ to thoroughly mix the solution. The $\mathrm{pH}$ of the solution was adjusted to 4.9 by adding a large volume of sodium acetate to the aceto-acetic buffer solution. Controlling the $\mathrm{pH}$ optimizes the hydrophilic-lipophilic balance of parasite eggs relative to the extraction medium, which helped to concentrate helminth eggs (AYRES et al., 1989). After homogenization, the samples were centrifuged at $2500 \mathrm{rpm}$ for $15 \mathrm{~min}$.

Following centrifugation, the samples presented four distinct layers. Fatty materials and heavy fragments, primarily composed of helminth eggs and larvae, as well as protozoa cysts and oocysts, were concentrated at the bottom of the tube. The other layers were composed mainly of buffer solution, grease, and other materials that mixed with the ether and formed a thick, dark-colored buffer layer. The top three layers were discarded and only material from the bottom layer was collected for analysis.

Zinc sulfate with a density of 1:35 was added to the pellets, at a ratio of $5 \times$ the pellet volume. The sample was further homogenized by vortexing for an additional $1 \mathrm{~min}$ and centrifuged at 3500rpm for 5min, which produced superior separation of eggs from the sediment. After centrifugation, an aliquot of the surface liquid layer was collected with a Pasteur pipette, placed in a McMaster chamber, and analyzed in triplicate. Readings were initiated after a 5-min wait to allow all eggs to float to the surface of the counting reticulum and were performed under $10 \times$ and $40 \times$ objectives of an optical microscope (Zeiss). Only eggs within the lattices of the McMaster chamber were counted; to ensure accuracy, the arithmetic average of the scores was calculated. The number of eggs per kilogram of compost was obtained by multiplying the average number of eggs counted in the three McMaster chambers by the volume $(\mathrm{mL})$ of the final pellet, dividing that figure by 0.30 (the volume in $\mathrm{mL}$ of the two reticles of a McMaster chamber), and multiplying by 1,000 (AYRES \& MARA, 1996).

The results are presented as means and standard errors. The data from the BM and MBA methods were analyzed with a Student's t-test, whereas all other data were subjected to ANOVA and post-hoc Dunnett's test, with $\mathrm{P}<0.05$.

\section{RESULTS}

Figure 1 shows the relative effectiveness of the BM and MBA methods for recovering eggs in composted material. Egg recovery was significantly higher using the MBA method than the BM approach $[\mathrm{t}(21)=2.02 ; \mathrm{P}<0.05]$, with $57 \%$ more eggs recovered.

Figure 2 compared the MBA method with the other techniques for recovering $\boldsymbol{A}$. suum eggs from compost (Figure 2A) and from LPM alone (Figure 2B). The MBA approach was significantly $(\mathrm{P}<0.005)$ more effective at recovering eggs from compost than were the WM, FM, and SS methods $(\mathrm{P}<0.05)$ (Figure 2A). The WM, FM, and SS method recovered only $4.4 \%, 13.9 \%$, and $26 \%$, respectively, of the number of eggs recovered using the MBA method. The MBA method was also significantly more effective at recovering eggs from LPM alone than were the WM $(\mathrm{P}<0.005)$ and the SS methods $(\mathrm{P}<0.05)$. The WM and SS method recovered only $30 \%$ and $56 \%$ of the number of eggs recovered by the MBA method from LPM. However, no significant differences were detected between the MBA method and the FM method $(\mathrm{P}>0.05)$ for egg recovery from LPM.

\section{DISCUSSION}

Several techniques have been developed to recover the eggs of helminths and protozoans from sewage sludge and wastewater generated by swine bioreactors (AYRES \& MARA, 1996; JEANDRON et al., 2014; PINTO et al., 2014). Although a number of these techniques have been shown to be effective for extracting eggs from feces and water, few studies have focused on their effectiveness at extracting eggs from waste material consisting of larger particles, which provide larger adhesion areas. Our results demonstrated the superiority of the MBA technique and advanced our knowledge onthe use of manure as fertilizer.

Research on the agronomic potential, greenhouse gas emissions, and pathogens associated with these types of wastes is quite extensive, with numerous studies published over the past decade alone (e.g., SÁ et al., 2014; BROETTO et al., 2015; CARVALHO et al., 2015; GONZATTO et al., 2016). However, evaluations are needed to testthe relative effectiveness of methods applied to waste treated by automated composting, which involves substrate material that provides a greater adhesion area for helminth and protozoa eggs. The present study added knowledge to this subjected, as we 


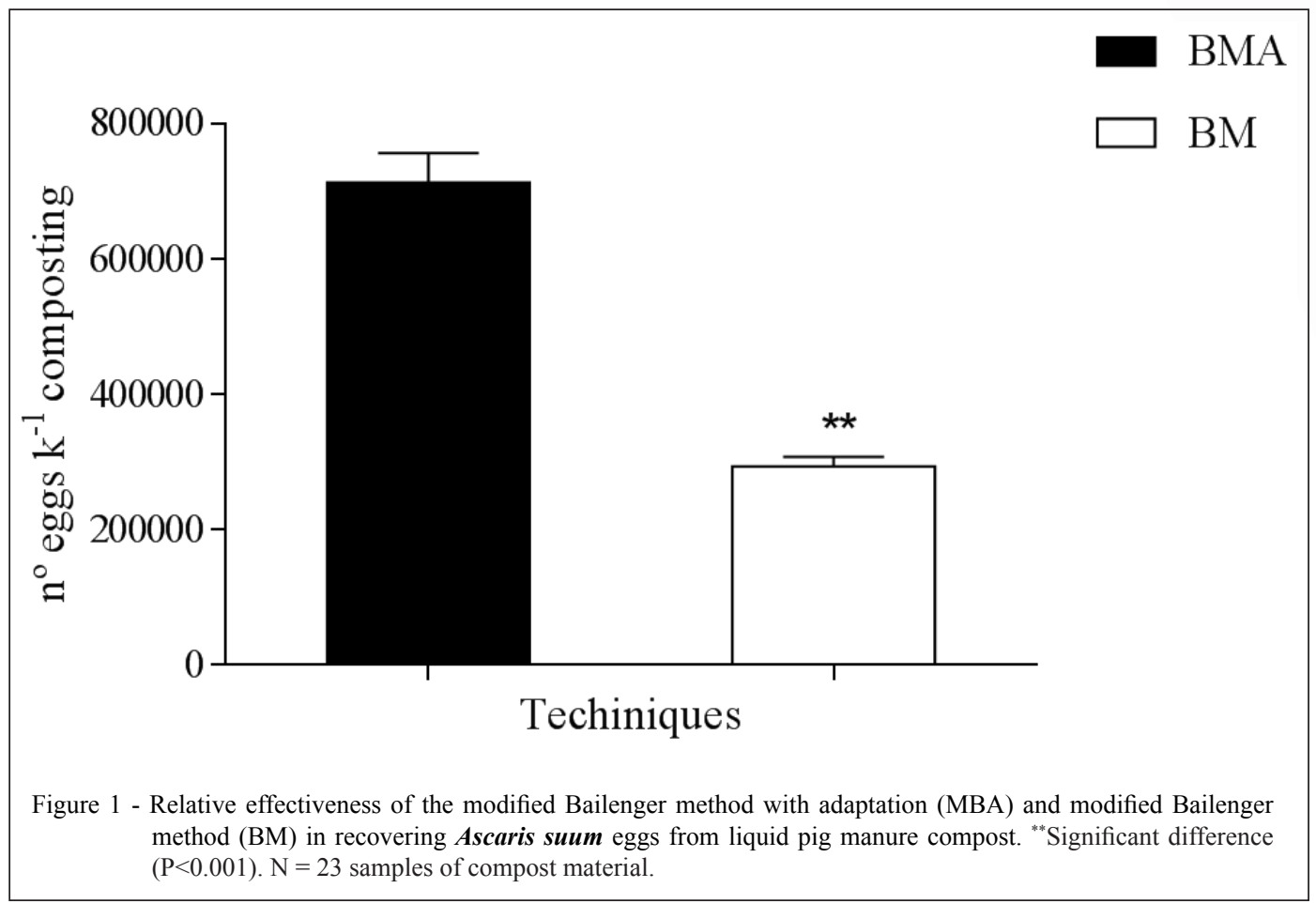

reported that modifying the BM technique improved the efficiency of helminth egg recovery by $57 \%$ over the traditional BM approach.

The BM is widely used to recover parasite eggs from sewage sludge and to treat manure in anaerobic reactors and biofilters. According to ZERBINI \& CHERNICHARO (2000), the BM does not capture the exact percentage of eggs recovered, but it is superior to other techniques used for treated sewage. However, the BM is less effective when the proportions of solids in the waste material are higher, as reported in previous studies, where helminth egg counts were low (SYLVESTRE, 2013).

We determined that significantly more eggs were recovered from the same sample by the MBA method than the BM (Figure 1), from which it can be inferred that agitation with deionized water and $1 \%$ Tween 80 at the beginning of the analysis helped detach eggs that were adhered to the substrate. Moreover, rinsing the substrate with $1 \%$ Tween 80 , along with centrifugation at the end of the procedure, may also have increased the efficiency of egg recovery. JEANDRON et al. (2014) achieved similar results, reporting that egg recovery rates increased from $82.7 \%$ to $96.5 \%$ when the detergent solution $1 \%$ Tween 80 was incorporated into samples seeded with helminth eggs.

According to AYRES \& MARA (1996), increasing the $\mathrm{pH}$ of the buffer solution improved the hydrophilic-lipophilic balance of parasite eggs relative to the extraction medium. We observed this phenomenon in the present study, as substituting deionized water for distilled water and increasing the $\mathrm{pH}$ of the aceto-acetic buffer solution to 4.9 resulted in better flotation of eggs than the conventional BM approach, which relied on lower $\mathrm{pH}$. Similarly, RITCHIE (1948) demonstrated that the effect of $\mathrm{pH}$ on egg-recovery efficiency varies among parasite species.

The adjustments to the BM also enabled the recovery of more eggs of other parasite species not covered in the present study relative to conventional methods. In a comparison of two solutions with densities greater than 1:20, MAGOTI (2008) did not observe any differences in egg recovery. However, in our study, increasing the density of the zinc sulfate solution to 1:35 improved egg flotation compared with the lower 1:18 density used in the conventional BM. Furthermore, adaptations to the BM enhanced sample clarity at the end of the process and thus improved egg visibility, which facilitated the McMaster chamber egg counts.

\section{CONCLUSION}

It is essential to know the extent of helminth egg contamination in LPM compost prior to using this waste material as a fertilizer for vegetable crops 


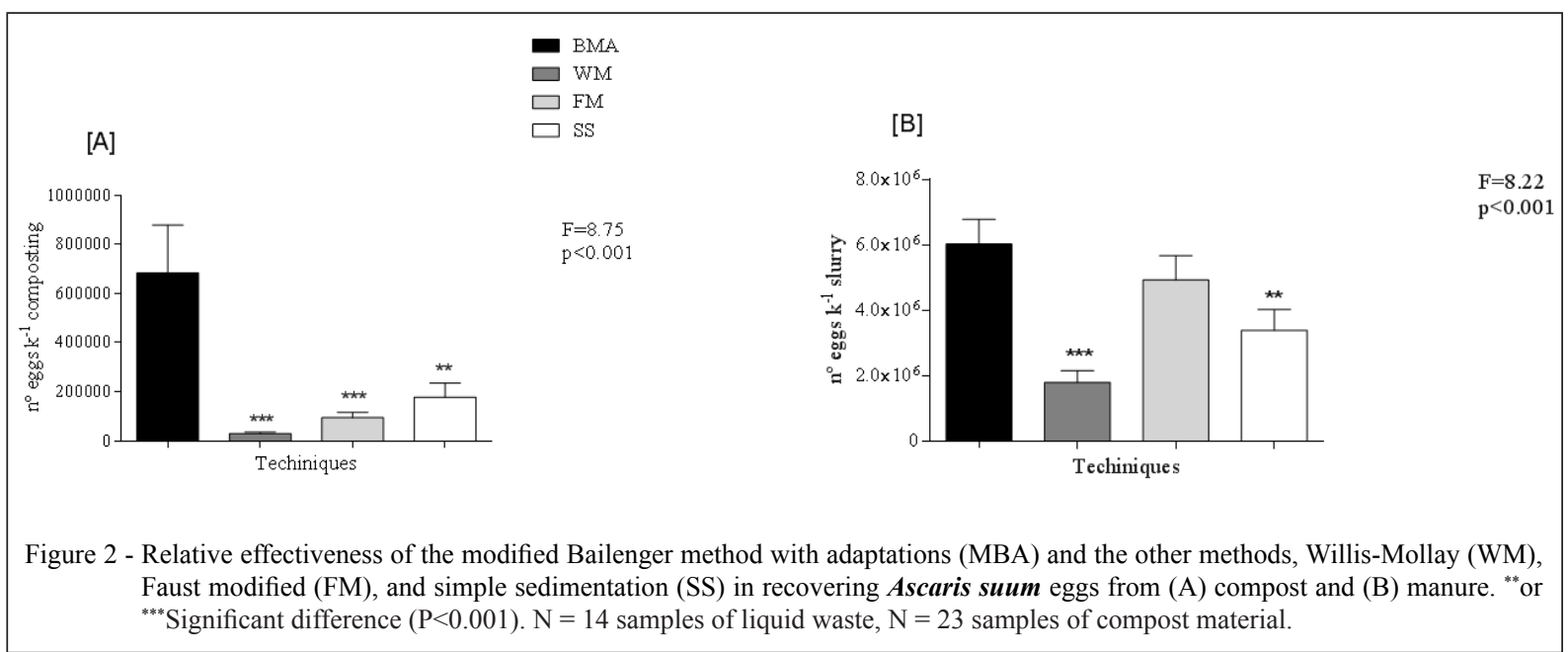

intended for human consumption. The adjustments we made to the BM greatly improved the technique's effectiveness as we measured the degree to which LPM compost was contaminated by $\boldsymbol{A}$. suum eggs.

\section{ACKNOWLEDGEMENTS}

The authors acknowledge funding from the Conselho Nacional de Desenvolvimento Científico e Tecnológico (CNPq) for financial support for this study.

\section{REFERENCES}

AYRES, R. et al. The enumeration of human intestinal nematode eggs in raw and treated wastewaters. Leeds, U.K.: Tropical Public Health Engineering, 1989. p. 617-623. <http:// dx.doi.org/10.1080/09593339109385048>.

AYRES, R.M.; MARA, D.D. Analysis of wastewater for use in agriculture: a laboratory manual of parasitological and bacteriological techniques. World Health Organization, 1996. 35p.

BROETTO, T. et al. Geospatial indicators to evaluate the environmental impact of swine production on licensing at municipal level. Pesquisa Agropecuária Brasileira, v.50, n.12, p.1177-1185, 2015. Available from: <http://www.scielo.br/pdf/ pab/v50n12/1678-3921-pab-50-12-01177.pdf $>$. Acessed: Aug. 16, 2016. Doi: 10.1590/S0100-204X2015001200007.

COELHO, W.M. et al. Avaliação de metodologias para detecção de ovos de helmintos no lodo e determinação do percentual de recuperação. In: CONGRESSO INTERAMERICANO DE INGENIERÍA SANITARIA Y AMBIENTAL, 28., 2002, Cancúm, México. Anais... Cancúm: ABES - Associação Brasileira de Engenharia Sanitária e Ambiental, 2002, CD room. p.1-7. Available from: <http://www.bvsde.paho.org/bvsaidis/mexico26/ iii-012.pdf $>$. Acessed: Nov. 13, 2015.

DOS SANTOS, L.D. et al. Technologies and treatment systems for pig farming waste. Revista Verde de Agroecologia e Desenvolvimento Sustentável, v.9, n.5, p.12-18, 2015. Available from: <http://www.gvaa.com.br/revista/index.php/RVADS/article/ view/2916/2927>. Accessed: Dec. 14, 2015

DOS SANTOS, L.U. et al. Detection of Cryptosporidium spp. oocysts and Giardia spp. cysts in raw and effluent wastewater: critical evaluation of methods. Engenharia Sanitaria e Ambiental, v.16, n.2, p.115-120, 2011. Available from: <http://www.scielo.br/ scielo.php?script=sci_arttext\&pid=S1413-41522011000200003>. Accessed: jan. 15,2016. Doi: 10.1590/S1413-41522011000200003.

GONZATTO, R. et al. Dicyandiamide as nitrification inhibitor of pig slurry ammonium nitrogen in soil. Ciência Rural, v.46, n.5, p.802-808, 2016. Available from: <http://www.scielo.br/ scielo.php?script $=$ sci_arttext\&pid $=\mathrm{S} 0103-84782016000500802>$. Accessed: dec. 12, 2016. Doi: 10.1590/0103-8478cr20141664.

HECK, K. et al. Evaluation of degradation temperature of compounds in a composting process and microbiological quality of the compost. Revista Brasileira de Engenharia Agrícola e Ambiental, v.17, n.1, p.54-59, 2013. Available from: <http://www.scielo.br/scielo. php? script $=$ sci_arttext\&pid $=$ S 1415-43662013000100008>. Accessed: sept. 13,2015. Doi: 10.1590/S1415-43662013000100008.

JEANDRON, A. et al. A quantitative assessment method for Ascaris eggs on hands. PLoS One, v.9, n.5, p.e96731, 2014. Available from: <http://journals.plos.org/plosone/ article?id=10.1371/journal.pone.0096731 $>$. Accessed: jan. 10, 2015. Doi: 10.1371/journal.pone.0096731.

JUNGERSEN, G. et al. Experimental transfer of Ascaris suum from donor pigs to helminth naïve pigs. Journal of Parasitology, v.82, p.752-756, 1996. Available from: <https://www.ncbi. nlm.nih.gov/pubmed/8885884>. Accessed: jan. 18, 2015. Doi: $10.2307 / 3283887$.

LELES, D. et al. Are Ascaris lumbricoides and Ascaris suum a single species? Parasites \& vectors, v.5, n.1, p.1, 2012. Available from: <http://parasitesandvectors.biomedcentral.com/ articles/10.1186/1756-3305-5-42>. Accessed: Feb. 14, 2016 Doi: $10.1186 / 1756-3305-5-42$.

MAGOTI, L.P. Padronização de técnica para recuperação de ovos de Toxocara canis em solo. Presidente Prudente: 
[s.n.], 2008. 38p. Available from: <http://www.unoeste. br/site/pos/enepe/anais/2008/docs/orais/enapi/expandido/ ExpandidoAgr\%C3\%A1riasVeterin\%C3\%A1riaOraisPesquisa. pdf\#page=28>. Accessed: Feb. 22, 2016.

OLIVEIRA, C.A.F.; GERMANO, P.M.L. Study on the occurrence of intestinal parasites on vegetables commercially traded in the metropolitan area of S. Paulo, SP, Brazil. I - Search for helminths. Revista de Saúde Pública, v.26, p.283-289, 1992. Available from: <http:/www.scielosp.org/scielo.php?pid=S003489101992000400011\&script $=$ sci arttext $>$. Accessed: Mar. 23, 2016. Doi: 10.1590/S0034-89101992000400011.

PALHARES, J.C. Impacto ambiental das produções pecuárias. In: CONGRESSO BRASILEIRO DE ANIMAIS SUSTENTÁVEL, 2012, Chapecó, SC. Anais... Brasília: EMBRAPA, 2012. 17p. Available from: <https://www. alice.cnptia.embrapa.br/alice/bitstream/doc/931701/1/ PROCI2011.00111.pdf>. Accessed: Aug. 16, 2016.

PINTO, A.C.A. et al. Employment of anaerobic reactors in real scale and polishing ponds for removal of eggs Ascaris suum of swine effluent. Semina: Ciências Agrárias, v.35, n.1, p.343-350, 2014. Available from: <http://www.redalyc.org/ articulo.oa?id=445744139028>. Accessed: Aug. 16, 2015. Doi: $10.5433 / 1679-0359$.

RITCHIE, L.S. An ether sedimentation technique for routine stool examination. Bulletin of the US Army Medical Department, v.8, p.326, 1948. Available from: <http://stimson.contentdm.oclc.org/ cdm/ref/collection/p15290coll6/id/3672>. Acessed: Aug. 11, 2015.

SÁ, M.F. et al. Population dynamics during composting of fecal automated pig slurry. Arquivo Brasileiro de Medicina Veterinária e Zootecnia, v.66, n.4, p.1197-1206, 2014. Available from: <http://www.scielo.br/scielo.php?pid=S0102$009352014000401197 \&$ script $=$ sci_arttext\&tlng=pt $>$. Accessed: jun. 6, 2016. doi: 10.1590/1678-6135.

SERPA F.R. et al. Compostagem de dejetos de suínos. Revista em Agronegócio e Meio Ambiente, v.6, n.1, p.47, 2013. Available from: <http://search.proquest.com/openview/9f3f ae6d3adcf5449704994b4b887dee/1?pq-origsite $=$ gscholar $>$. Accessed: Dec. 27, 2016.

SYLVESTRE, S.H.Z. Desempenho de sistemas de reatores anaeróbios e aeróbio na remoção de coliformes e ovos de helmintos de águas residuárias de suinocultura. Local: Universidade Estadual Paulista - UNESP, 2013. p.30-47, 2013. Available from: <http://repositorio.unesp.br/bitstream/ handle/11449/94799/000738778.pdf? sequence=1\&isAllowed=y $>$. Accessed: jan. 27, 2016.

ZERBINI, A.M.; CHERNICHARO, C.A.L. Proposta de consolidação de metodologias para enumeração, identificação e análise de viabilidade de ovos de helmintos em águas residuárias brutas e tratadas: pós-tratamento de efluentes de reatores anaeróbio. Belo Horizonte: ABES-PROSAB, 2000. Total de p. 157. 